\title{
Development of high-performance thin-layer chromatography method for herbals identification in extemporaneous oral solution
}

\author{
K. O. Khokhlova, O. A. Zdoryk \\ National University of Pharmacy, Kharkiv, Ukraine
}

Key words:

HPTLC

identification,

valerenic acids,

flavonoids,

extemporal

preparations.

\section{Zaporozhye}

medical journal

2018; 20 (1), 116-120

DOI:

$10.14739 / 2310-1210$

2018.1.122128

E-mail:

kateryna_khokhlova@

ukr.net
The preparation of extemporal medicines in store includes carrying out intrapharmacy quality control and stability studies. Since there is no single analytical method that ideally suited for all drugs, for each formulation depend on its composition and analytical goal, appropriate quality control methods should be developed. The object of analysis was pediatric oral solution with sedative action that contains Valerian tincture, Motherwort tincture, and sodium bromide.

The purpose of research was the development of simple, specific and reproducible methods of active herbal ingredients identification formulated into oral solution.

Materials and methods. The high-performance thin-layer chromatography (HPTLC) was used as the method for analysis. It was performed on $200 \times 100 \mathrm{~mm}$ silica gel $60 \mathrm{~F} 254$ HPTLC glass plates (Merck, Germany). Standard solutions and samples were applied onto the plate as bands $8.0 \mathrm{~mm}$ wide using spray-on technique with Automatic TLC sampler ATS 4; the development was made in saturated Automatic developing chamber ADC 2, temperature and the relative humidity were $23{ }^{\circ} \mathrm{C}$ and $33 \%$ respectively; the derivatization was performed using Chromatogram Immersion Device; the documentation was conducted using Visualizer with visionCATS software (CAMAG, Switzerland).

As a result two HPTLC identification methods have been developed for valerenic acids that are specific for Valerian tincture and flavonoids that are specific for Motherwort tincture. Thus, the sample preparation has been developed, the optimal chromatographic conditions have been chosen, the acceptance criteria have been proposed, and the reference chromatograms have been shown. Valerenic acids of oral solution were determined in mobile phase: cyclohexane, ethyl acetate, acetic acid (60:38:2); the derivatization of plates was performed through dipping with Anisaldehyde-sulfuric acid reagent and heated to $100{ }^{\circ} \mathrm{C}$ for $3 \mathrm{~min}$; documentation was performed after derivatization under white light and UV $366 \mathrm{~nm}$. Flavonoids of oral solution were determined in mobile phase: ethylacetate, methyl ethyl ketone, formic acid, water (5:3:1:1); the derivatization of plates was performed through dipping with Natural Products/PEG reagents, heated to $100{ }^{\circ} \mathrm{C}$ for 3 min before dipping; documentation was performed after derivatization under UV $366 \mathrm{~nm}$.

Conclusions. The developed methods can be used for identification of oral solution, and for stability study with the purpose of determination of its storage conditions and shelf-life.

\section{Кнючові слова:}

BETШX,

іАентифікація,

валеренові

кислоти,

флавоноїаи,

екстемпоральні

мікарські засоби.

\section{Запорізький \\ медичний \\ журнал. - 2018. - \\ T. 20, № 1(106). -}

C. $116-120$

\section{Розробка методики високоефективної тонкошарової хроматографії Аля ідентифікації рослинних компонентів в екстемпоральній мікстурі}

\section{К. О. Хохиова, О. А. ЗАорик}

Виготовлення екстемпоральних лікарських засобів про запас включає проведення внутрішньоаптечного контролю та дослідження стабільності. Оскільки немає універсальних аналітичних методів, що придатні для аналізу всіх ліків, для кожного пропису, залежно від складу та мети, повинні бути розроблені належні методи контролю якості. Об'єктом дослідження стала дитяча мікстура заспокійливої дії, яка містить настойку валеріани, настойку собачої кропиви та натрію бромід.

Мета роботи - розроблення простих, специфічних і відтворюваних методик ідентифікації активних рослинних інгредієнтів, які входять до складу мікстури.

Матеріали та методи. Для аналізу обрали метод високоефективної тонкошарової хроматографії (ВЕТШХ). Аналіз здійснили на ВЕТШХ пластинках розміром 200 × 100 мм на силікагелі 60 F 254 (Merck, ФРН). Випробовуваний розчин і розчини порівняння наносили смугами завдовжки 8 мм розпиленням, застосовуючи пристрій для автоматичного нанесення ATS 4; хроматографування виконали в насиченій хроматографічній камері ADC 2 при температурі $23^{\circ} \mathrm{C} i$ відносній вологості 33 \%; проявлення здійснювали, використовуючи пристрій для занурення; документування проводили у візуалайзері з програмним забезпеченням visionCATS (CAMAG, Швейцарія).

Результати. Розроблено дві методики ідентифікації для визначення валеренових кислот, специфічних для настойки валеріани, та флавоноїдів, специфічних для настойки собачої кропиви. Підібрана пробопідготовка, оптимальні умови хроматографування, запропоновані критерії прийнятності та наведені хроматограми-порівняння. Валеренові кислоти у складі мікстури визначали в рухомій фазі: циклогексан, етилацетат, кислота оцтова (60:38:2); для виявлення використовували анісового альдегіду розчин, нагрівали пластинку при $100{ }^{\circ} \mathrm{C}$ протягом 3 хв; задокументовували у білому світлі та УФ 366 нм. Для визначення фрлавоноїдів у складі мікстури використовували рухому фазу: етилацетат, метилетилкетон, мурашина кислота, вода (5:3:1:1); при визначенні занурювали пластинку в реагенти аміноетилового ефіру дифенілборної кислоти та макрогол, попередньо нагрівали пластинку при $100{ }^{\circ} \mathrm{C}$ протягом 3 хв; документування проводили в УФ 366 нм.

Висновки. Розроблені методики можуть використовуватись для ідентифікації мікстури та під час вивчення ії стабільності з метою визначення умов і терміну зберігання. 


\title{
Разработка методики высокоэффективной тонкослойной хроматографии Аля идентификации растительных компонентов в экстемпоральной микстуре
}

\author{
Е. А. Хохлова, А. А. Здорик
}

Приготовление экстемпоральных лекарственных средств про запас включает проведение внутриаптечного контроля и исследование стабильности. Поскольку не существует универсальных аналитических методов, пригодных для анализа всех лекарств, для каждой прописи, в зависимости от состава и целей, должны быть разработаны надлежащие методы контроля качества. Объектом исследования была детская микстура седативного действия, содержащая настойку валерианы, настойку пустырника и натрия бромид.

Цель работы - разработка простых, специфичных и воспроизводимых методик идентификации активных растительных ингредиентов, входящих в состав микстуры.

Материалы и методы. Для анализа выбран метод высокоэффективной тонкослойной хроматографии (BЭТСХ). Анализ проводили на ВЭТСХ пластинках размером 200 × 100 мм на силикагеле 60 F 254 (Merck, ФРГ). Испытуемый раствор и растворы сравнения наносили полосами длиной 8 мм распылением, применяя устройство для автоматического нанесения ATS 4; хроматографирование проводили в насыщенной хроматографической камере ADC 2 при температуре $23^{\circ} \mathrm{C}$ и относительной влажности 33 \%; проявление осуществляли, используя устройство для погружения; документирование проводили в визуалайзере с программным обеспечением visionCATS (CAMAG, Швейцария).

Результаты. Разработаны две методики идентификации для определения валереновых кислот, специфичных для настойки валерианы, и фрлавоноидов, специфичных для настойки пустырника. Была подобрана пробоподготовка, оптимальные условия хроматографирования, предложены критерии приемлемости и приведены хроматограммы-сравнения. Валереновые кислоты в составе микстуры определяли в подвижной фазе: циклогексан, этилацетат, кислота уксусная (60:38:2); для обнаружения использовали анисового альдегида раствор, нагревали пластинку при $100{ }^{\circ} \mathrm{C}$ в течение 3 мин; документирование проводили в белом свете и УФ 366 нм. Для определения фравоноидов в составе микстуры использовали подвижную фазу: этилацетат, метилэтилкетон, муравьиная кислота, вода (5:3:1:1); обнаружение проводили погружением в реагенты аминоэтилового эфира дифенилборной кислоты и макрогол, предварительно нагрев пластинку при $100{ }^{\circ} \mathrm{C}$ в течение 3 мин; документирование проводили в УФ 366 нм.

Выводы. Разработанные методики могут быть использованы для идентификации микстуры, а также при изучении ее стабильности с целью определения условий и срока хранения.

\section{Introduction}

A quality control in store compounded preparations must include some levels of analytical testing. The goal in analytical testing is to produce results as accurately, efficiently and quickly as possible. Any analytical method should have accuracy, speed, reproducibility and specificity. No single analytical method is ideally suited for all drugs; each method has its own strengths and weaknesses, and there are a number of factors that determine the reliability of results [1].

Compounding pharmacies have two options regarding analytical testing. Some relatively simple analytical methods can easily be performed in-house (in the pharmacy), but some need to be outsourced to a contract laboratory. Analytical methods that can be outsourced to a contract laboratory include chromatography: high-performance liquid chromatography (HPLC) and gas chromatography (GC); mass spectroscopy (MS), hyphenated methods (HPLC-MS) and GC-MS, ultraviolet (UV) and visible spectroscopy and other sophisticated methods [1]. Also these methods could be used for stability study of preparations.

One of the widely used compounded preparations with sedative action that often is prescribed for pediatric treatment in Ukraine is oral drops with herbals. It is prepared in the compounded pharmacy "Leda", Kharkiv, Ukraine. The compounded oral solution has such composition: Leonuri cardiaca tinctura $7 \mathrm{~mL}$; Valerianae officinalis tinctura $7 \mathrm{~mL}$; Sodium bromide solution $2 \%$ to $200 \mathrm{~mL}$.

The purpose of this paper was to develop simple, specific and reproducible methods of active herbal ingredients identification formulated into oral solution.

\section{Materials and methods}

Chromatography. HPTLC analysis was performed on $200 \times 100$ mm silica gel 60 F 254 HPTLC glass plates (Merck, Germany). Standard solutions and samples were applied onto the plate as bands $8.0 \mathrm{~mm}$ wide using CAMAG spray-on technique with Automatic TLC sampler (ATS 4). The development was made in saturated CAMAG Automatic developing chamber (ADC 2). The temperature and the relative humidity within the developing chamber (ADC 2) were $23{ }^{\circ} \mathrm{C}$ and $33 \%$ respectively. The derivatization was performed using CAMAG Chromatogram Immersion Device. The documentation was conducted using CAMAG Visualizer with visionCATS software. Other apparatus were used: Tube Mill control (IKA); Centrifuge EBA21 (Hettich, Germany); Ultrasonic Bath SW 3H (Sono Swiss); Analytical Balance MS 205 DU (Mettler-Toledo).

\section{Results and discussion}

According to the numerous publications published in peer-reviewed journals and books the main method which is used for identification of herbals or herbal combinations is TLC or its modern version HPTLC [2-6]. The TLC/HPTLC methods are used for pharmacopoeia identification of initial herbal raw material of oral drops, such as Valerian root and Motherwort herb and its tinctures [7-9]. The general procedure of TLC/HPTLC development of methods for identification of herbals includes selection of marker compounds and evaluation and optimization of existing methods $[2,6]$. With respect to the development of identification methods for the active ingredients of oral drops the chromatographic conditions for TLC/HPTLC identification for Valerian and
Ключевые слова: ВЭТСХ, идентификация, валереновые кислоты, флавоноиды, экстемпоральные мекарственные средства.

Запорожский медицинский журнак. - 2018. T. 20, № 1(106). C. $116-120$ 
Table 1. Comparison of thin-layer and high-performance thin-layer chromatographic conditions for Valerian

\begin{tabular}{|c|c|c|}
\hline Pharmacopoeia & USP & EPh \\
\hline Standard solutions & $\begin{array}{l}\text { Valerenic Acid } \\
\text { Powdered Valerian Extract }\end{array}$ & $\begin{array}{l}\text { Fluorescein } \\
\text { Sudan red }\end{array}$ \\
\hline Sample solution & $\begin{array}{l}0.1 \mathrm{~g} / \mathrm{ml} \text { valerian solution } \\
\text { in methanol }\end{array}$ & $\begin{array}{l}\text { - Extraction, filtration } \\
\text { - Dilution } \\
\text { - Evaporation } \\
\text { - Reaction with alkali solution } \\
\text { - Two times extraction } \\
\text { - Separation of layers } \\
\text { - Heating, cooling } \\
\text { - Reaction with acid solution } \\
\text { - Two times extraction } \\
\text { - Separation of layers and filtration } \\
\text { - Evaporation } \\
\text { - Dissolution }\end{array}$ \\
\hline Adsorbent & HPTLC plates & TLC plates \\
\hline Mobile phase & $\begin{array}{l}\text { Cyclohexane, ethyl acetate } \\
\text { and acetic acid (60:38:2) }\end{array}$ & $\begin{array}{l}\text { Glacial acetic acid, ethyl acetate, } \\
\text { hexane }(0.5: 35: 65)\end{array}$ \\
\hline Derivatization reagent & $\begin{array}{l}\text { A. Mixture of glacial acetic acid } \\
\text { and hydrochloric acid }(1: 4) \text {; } \\
\text { heat at } 120^{\circ} \mathrm{C} \text { for } 5 \mathrm{~min} \text {, white light } \\
\text { B. Anisaldehyde reagent, } \\
\text { heat at } 100^{\circ} \mathrm{C} \text { for } 3 \mathrm{~min} \text {, white light }\end{array}$ & $\begin{array}{l}\text { Anisaldehyde reagent, heat at } 100- \\
105^{\circ} \mathrm{C} \text { for } 5-10 \mathrm{~min} \text {, white light }\end{array}$ \\
\hline Relative humidity & $33 \%$ & - \\
\hline
\end{tabular}

Table 2. Comparison of thin-layer chromatographic conditions for Motherwort and Motherwort tincture

\begin{tabular}{|c|c|c|c|}
\hline Pharmacopoeia & $\mathrm{EPh}$ & SPhU & SPhU \\
\hline Monograph & Leonurus herb & Leonurus & Leonurus tincture \\
\hline $\begin{array}{l}\text { Class of bioactive } \\
\text { substances }\end{array}$ & Iridoids & Iridoids, flavonoids & Iridoids, flavonoids \\
\hline Standard solutions & Naphtol yellow, catalpol & Hyperoside, rutin & Hyperoside, rutin \\
\hline Sample solution & $1 \mathrm{mg} / \mathrm{ml}$ in methanol & $\begin{array}{l}\text { Steps: } \\
\text { - Extraction } \\
\text { - Heating } \\
\text { - Cooling } \\
\text { - Filtration } \\
\text { - Evaporation } \\
\text { - Filtration } \\
\text { - Extraction 1 } \\
\text { - Extraction } 2 \\
\text { - Evaporation } \\
\text { - Dissolution }\end{array}$ & $\begin{array}{l}\text { Steps: } \\
\text { - Evaporation } \\
\text { - Dilution } \\
\text { - Filtration } \\
\text { - Extraction } 1 \\
\text { - Extraction } 2 \\
\text { - Evaporation }\end{array}$ \\
\hline Adsorbent & TLC plate & TLC plate & TLC plate \\
\hline Mobile phase & $\begin{array}{l}\text { Glacial acetic acid, water, } \\
\text { ethyl acetate }(20: 20: 60)\end{array}$ & $\begin{array}{l}\text { Glacial acetic acid water, } \\
\text { ethyl acetate }(20: 20: 60)\end{array}$ & $\begin{array}{l}\text { Glacial acetic acid, } \\
\text { water, ethyl acetate } \\
(20: 20: 60)\end{array}$ \\
\hline $\begin{array}{l}\text { Derivatization } \\
\text { reagent }\end{array}$ & $\begin{array}{l}\text { Dimethylaminobenzal- } \\
\text { dehyde solution }\end{array}$ & $\begin{array}{l}\text { Dimethylaminobenzal- } \\
\text { dehyde solution }\end{array}$ & $\begin{array}{l}\text { Dimethylaminobenzal- } \\
\text { dehyde solution }\end{array}$ \\
\hline $\begin{array}{l}\text { Relative } \\
\text { humidity, \% }\end{array}$ & - & - & - \\
\hline
\end{tabular}

Motherwort from different world leader pharmacopoeia were compared. The results are shown in the Table 1-2.

As we can see from the Table 1, the sample preparation from European pharmacopoeia (EPh) is cumbersome and includes time-consuming steps, while the desirable aspects of practical method are its simplicity and clarity [8]. The reference substances which are used in EPh are not specific. The conventional TLC plates are used, the relative humidity are not controlled. As specific components of Valeriana officinalis are sesquiterpene carboxylic acids $[8,10,11]$ - mobile phase: cyclohexane, ethyl acetate, acetic acid (60:38:2) for valerenic acids was considered as appropriate for further investigation. That is why the next step was the development of sample preparation and optimization of the method from the United State Pharmacopoeia (USP).
Development of sample preparation for sesquiterpene carboxylic acids. Since the oral formulation is a water solution, which is a very polar solvent and cannot be applied directly onto the plate the modern function of CAMAG ATS 4, which is called "nozzle heating" was used. Four different volumes of compounding preparation's sample were applied onto the plate: $10.0 \mu \mathrm{L}, 20.0 \mu \mathrm{L}, 35.0 \mu \mathrm{L}$ and $40.0 \mu \mathrm{L}$ and results were compared. The obtained zones of fingerprints of different volumes after the usage of "nozzle heating" had wrong shapes and tails, thus results were considered as not appropriate.

Hence, the next step of sample preparation development included comparison of different solvents: methanol, butanol, toluene and different application volumes of each solvent: $5 \mu \mathrm{L}, 10 \mu \mathrm{L}, 15 \mu \mathrm{L}$. The plate after derivatization with Anisaldehyde-sulfuric acid reagent under the white light with different sample preparation of oral solution has been shown on the Fig. 1.

As we can see on the Fig. 1 the best results were obtained with $5 \mu \mathrm{L}$ of butanol solvent. With this solvent sesquiterpene carboxylic acids which are specific for Valerian root and Valerian tincture are moved to compounding oral solution and can be used as specific markers.

In final method the optional reference substances (hydroxyvalerenic acid, acetoxyvalerenic acid and/or mixture of herbal tinctures, prepared from authentic raw materials) and optional detection mode comparing to the method from USP [8] can be used.

As we can see from the Table 2, according to the EPh for identification of Leonurus cardiaca herb iridoid's chromatographic profile is used; the reference substances naphtol yellow and catalpol are not specific [7]. According to the State Pharmacopoeia of Ukraine (SPhU) there are two monographs: for Leonurus herb and Leonurus tincture [9]. The same mobile phase and the same derivatization reagent as in EPh are used in SPhU. But specific and cumbersome sample preparations in SPhU give the possibility to determine not just the iridoids but also the flavonoids profile with the usage of typical markers for flavonoids. The conventional TLC plates are used in both methods from $\mathrm{SPhU}$ and EPh, the relative humidity are not controlled.

As flavonoids are the specific components for Leonurus cardiaca and could help to differentiate it from other ingredients in oral solution [10], this class of substances were chosen for identification of oral solution. As mobile phase a typical system for flavonoids from EPh: ethyl acetate, methyl ethyl ketone, formic acid, water (5:3:1:1) and typical flavonoids' markers (hypersoside, rutin) were used.

Development of sample preparation for flavonoids. During development of HPTLC method for flavonoids the same approach as for valerenic acids was used. The application of different volumes of water solution with "nozzle heating" function was considered as not appropriate. The obtained zones of flavonoids fingerprints had wrong shapes, tails, and change positions comparing to markers in fingerprints of Motherwort herb and tincture that were used as reference standards.

Thus, further development of sample preparation for flavonoids included comparing of different solvents: methanol, butanol, toluene and different application volumes of each solvent: $5 \mu \mathrm{L}, 10 \mu \mathrm{L}, 15 \mu \mathrm{L}$ (Fig. 2).

As we can see on the Fig. 2 the best results with "clear" fingerprints on the plate after derivatization with 
NP/PEG reagent under the $366 \mathrm{~nm}$ were obtained with 5 $\mu \mathrm{L}$ of butanol solvent. With this solvent, flavonoids which are specific for Motherwort herb and Motherwort tincture are moved to compounding oral solution and can be used as specific markers.

The final HPTLC methods for identification of herbal ingredients in composition of oral solution are shown below.

Proposed High-Performance Thin-Layer Chromatographic Identification Test

Preparations of sample solution

$10 \mathrm{ml}$ of compounding oral solution was evaporated on rotor evaporator to dry residue (pressure under the 76 mbar, $\mathrm{t}=50^{\circ} \mathrm{C}$ ). The dry residue was cooled and $2 \mathrm{ml}$ of butanol was added. The resultant was allowed to stand for 5-10 $\mathrm{min}$ and sonicated for $3 \mathrm{~min}$. The supernatant was used as test solution for HPTLC analysis.

Method A. Sesquiterpene carboxylic acids (valerenic acids)

Standard solution $A$. The reference standard solution of valerenic acid was prepared at concentration of $0.25 \mathrm{mg} / \mathrm{ml}$ in methanol, and then submitted for HPTLC analysis.

Standard solution $B$ (optional). $1 \mathrm{ml}$ of valerian tincture and $1 \mathrm{ml}$ of motherwort tincture was mixed thoroughly and centrifuged for $5 \mathrm{~min}$ at $5000 \mathrm{rpm}$. The supernatant solution was used for HPTLC analysis.

Mobile phase. Cyclohexane, ethyl acetate, acetic acid (60:38:2).

Application volume. $5 \mu \mathrm{L}$ of sample and standard solutions.

Derivatization. The derivatization of plates was performed through dipping (Speed: 5, time: 0) with Anisaldehyde-sulfuric acid reagent using CAMAG Chromatogram Immersion Device and heated to $100{ }^{\circ} \mathrm{C}$ for $3 \mathrm{~min}$ on the TLC plate heater. The plates were documented using CAMAG Visualizer after derivatization under white light and (optional) UV $366 \mathrm{~nm}$ with visionCATS software.

Acceptance criteria. Compare result with the reference images. The fingerprint of the test solution is similar to that of the sample of compounding preparation (Fig. 1, track 8). Additional weak zones may be present.

After derivatization with Anisaldehyde-sulfuric acid reagent under white light the test solution shows two major violet zones in the center part of chromatogram: one zone corresponding to valerenic acid and another zone below it corresponding to acetoxyvalerenic acid (blue arrows), between these two zones one or two violet zones of low intensity; a minor violet zone corresponding to hydroxyvalerenic acid in the lower third of chromatogram.

\section{Method B. Flavonoids}

Standard solution $A$. The reference standard solutions of rutin and hyperoside were prepared at methanol concentration of $1.0 \mathrm{mg} / \mathrm{ml}$, and then submitted for HPTLC analysis.

Standard solution $B$ (optional). $1 \mathrm{ml}$ of valerian tincture and $1 \mathrm{ml}$ of motherwort tincture was mixed thoroughly and centrifuged for $5 \mathrm{~min}$ at $5000 \mathrm{rpm}$. The supernatant solution was used for HPTLC analysis.

Mobile phase. Ethylacetate, methyl ethyl ketone, formic acid, water (5:3:1:1).

Application volume. $5 \mu \mathrm{L}$ of sample and standard solutions.

Derivatization. The derivatisation of plates was performed through dipping (Speed: 5, time: 0) with Natural

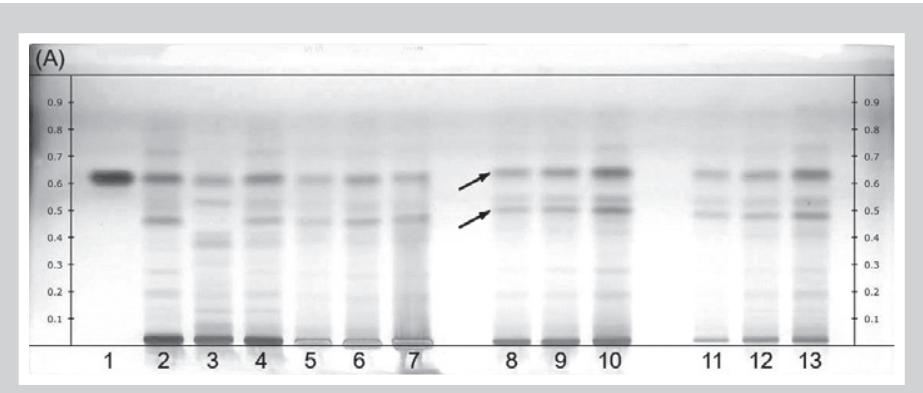

Fig. 1. Development of HPTLC method for identification of sesquiterpene carboxylic acids. Developing solvent: cyclohexane, ethyl acetate, acetic acid (60:38:2); derivatization: anisaldehyde reagent; detection: white light.

Tracks: 1 - valerenic acid, $5 \mu l ; 2$ - valerian tincture (1:10), $70 \%$ alcohol, $5 \mu l ; 3$ - motherwort tincture, (1:10), $70 \%$ alcohol, $5 \mu \mathrm{l} ; 4$ - mixture of valerian and motherwort tinctures, 5 $\mu \mathrm{l} ; 5-13$ - samples of compounding oral solution: $5-7$ - solvent - methanol, $5,10,15 \mu \mathrm{l}$ respectively; 8-10 - solvent - butanol, 5, 10, $15 \mu$ respectively; 11 - 13 - solvent - toluene, 5, 10, $15 \mu \mathrm{l}$ respectively.

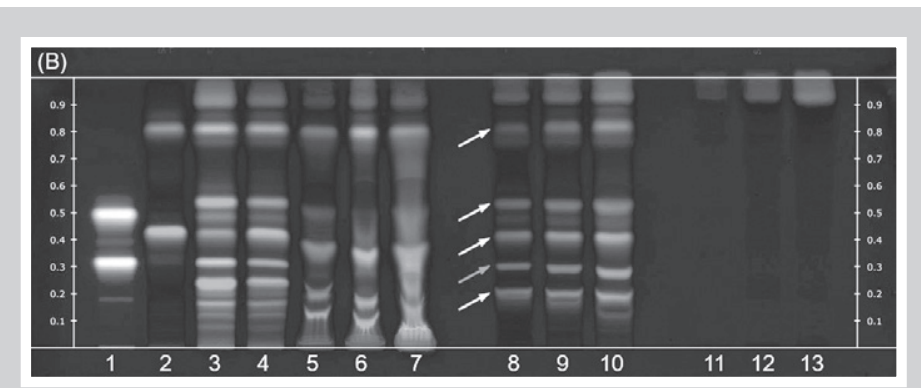

Fig. 2. Development of HPTLC method for identification of flavonoids. Developing solvent: ethylacetate, methyl ethyl ketone, formic acid, water (5:3:1:1); derivatization: NP/PEG; detection: $366 \mathrm{~nm}$.

Tracks: 1 - rutin, hyperoside, $5 \mu$ l; 2 - valerian tincture (1:10), $70 \%$ alcohol, $5 \mu$ l; 3 motherwort tincture, (1:10), $70 \%$ alcohol, $5 \mu \mathrm{l} ; 4$ - mixture of valerian and motherwort tinctures, $5 \mu \mathrm{l} ; 5-13$ - samples of compounding oral solution: $5-7$ - solvent-methanol, 5, 10, $15 \mu \mathrm{l}$ respectively; 8-10-solvent - butanol, 5, 10, $15 \mu$ respectively; $11-13$ - solvent - toluene, $5,10,15 \mu$ respectively.

Products/Polyethylene glycol (NP/PEG) using CAMAG Chromatogram Immersion Device. The plate is heated at $100{ }^{\circ} \mathrm{C}$ for 3 min on the TLC plate heater, then immersed while still hot in $5 \mathrm{~g} / \mathrm{L}$ solution of diphenylboric acid aminoethyl ester in ethyl acetate, dried in a stream of cold air, then dipped in $50 \mathrm{~g} / \mathrm{L}$ solution of macrogol 400 in methylene chloride. The plates were documented using CAMAG Visualizer after derivatization under UV $366 \mathrm{~nm}$ with visionCATS software.

Acceptance criteria. Compare result with reference images. The fingerprint of the test solution is similar to that of the sample of compounding preparation (Fig. 2, track 8). Additional weak zones may be present.

Afterderivatization with NP/PEG reagentunderUV366 nm the test solution shows orange fluorescent zone (red arrow) corresponding to reference substance rutin in the low third of chromatogram; four blue fluorescent zones (white arrows) - two in the center part of chromatogram one above, other below the zone corresponding to reference substance hyperoside; one in the upper part of chromatogram close to the front position; another in the lower third of chromatogram below the zone corresponding to rutin. 


\section{Conclusions}

As a result two simple, specific and reproducible HPTLC identification methods of herbal ingredients of compounded oral solution were developed. For this purpose the choice of specific groups of bioactive substances/markers of oral solution has been done (valerenic acids and flavonoids), sample and standards preparations have been developed, chromatographic conditions have been chosen, acceptance criteria have been proposed, reference images of chromatogram have been shown. The developed HPTLC methods could be used for chemical stability study of compounding preparation to determine storage conditions and shelf-life of the oral solution.

Acknowledgements. Thanks to CAMAG and the Head of the CAMAG laboratory, Dr. Eike Reich, PhD and Mr. Raphael Vizzini personally for financial and scientific support in conducting research on the base of CAMAG, Muttenz, Switzerland.

\section{References}

[1] Allen, L. (2012). Basics of Compounding: Implementing United States Pharmacopeia Chapter $<1163>$ Quality Assurance in Pharmaceutica Compounding, Part 3: Testing. International Journal Pharmaceutical Compounding, 16(4), 322-328.

[2] Reich, E., \& Schibli, A. (2007). High-performance thin-layer chromatography for the analysis of medicinal plants. New-York: Thieme.

[3] Reich, E., Schibli, A., \& DeBatt, A. (2008). Validation of high-performance thin-layer chromatographic methods for the identificaion of botanicals in a GMP. Journal of AOAC International, 91(1), 13-20.

[4] Zdoryk, O. A., Khokhlova, K. O., Georgiyants, V. A., \& Vyshnevska, L. I. (2014). Investigation of Physical and Chemical Stability of Ointmen with Herbals. International Journal Pharmaceutical Compounding, 18(3), 248-252.

[5] Khokhlova, K. O. (2016). Kontrol' kachestva nastojki boyaryshnika metodom VE'TSH [Quality control of hawthorn tincture by HPTLC method]. Annaly Mechnykovskoho instytutu, 3, 56-60. [in Russian].

[6] Khokhlova, K. O., Vyshnevska, L. I., Harna, S. V., \& Kotov, A. H. (2013). Rozrobka ta validatsiia metodyky identyfikatsii izoflavonoidiv i tryterpenovykh saponiniv u nastoitsi «Aterofit-norma» metodom tonkosharovoi khromatohrafii [Development and validation of the method of identification of isoflavonoids and triterpenoid saponins in the tincture «Aterofit-norma» by TLC]. Farmakom, 1, 38-51. [in Ukrainian].

[7] (2007) European Pharmacopoeia. Strasbourg.

[8] (2017). USP39-NF34. Rockville. Retrieved from http:/www.usp.org/ sites/default/files/usp_pdf/EN/products/usp39-nf34-index-supplement1.pdf.

[9] Derzhavne pidpryiemstvo «Ukrainskyi naukovyi farmakopeinyi tsentr yakosti likarskykh zasobiv» (2014) Derzhavna farmakopeia Ukrainy [State Pharmacopoeia of Ukraine]. (Vol. 3). Kharkiv. [in Ukrainian].

[10] Barnes, J., Anderson, L., \& Phillipson, P. (2007). Herbal Medicines. London: PhP.

[11] Wagner, H., Bladt, S., \& Zgainski, E. (1984). Plant drug analysis. Berlin: Springer-Verlag.

\section{Information about authors:}

Khokhlova K. O., PhD, Assistant, Department of Pharmaceutical

Technology of Drugs, National University of Pharmacy, Kharkiv, Ukraine.

Zdoryk 0. A., PhD, Associate Professor, Dean of the Faculty of Industrial Pharmacy, Management and Administration, National University of Pharmacy, Kharkiv, Ukraine.

\section{Відомості про авторів:}

Хохлова К. О., канА. фарм. наук, асистент каф. аптечної технології ліків, Національний фармацевтичний університет, м. Харків, Україна.

ЗАорик 0. А., канд. фарм. наук, Аоцент, Аекан факультету промислової фармації, управління та аАміністрування, Національний фармацевтичний університет, м. Харків, Україна.

\section{Сведения об авторах}

Хохлова Е. А., канА. фарм. наук, ассистент каф. аптечной технологии лекарств, Национальный фармацевтический университет, г. Харьков, Украина.

ЗАорик А. А., канА. фарм. наук, Аоцент, Аекан факультета промышленной фармации, управления и аАминистрирования, Национальный фармацевтический университет, г. Харьков, Украина.

Conflicts of Interest: authors have no conflict of interest to declare. Конфмікт інтересів: віАсутній.

Надійшла Ао редакції / Received: 30.08.2017

Після Аоопрацювання / Revised: 07.09.2017

Прийнято Ао Аруку / Accepted: 08.09.2017 